\title{
Jeritan Perempuan yang Terkungkung Sistem Patriarki dalam Kumpulan Cerita Pendek Akar Pule: suatu Tinjauan Feminisme Radikal
}

\author{
Zahratul Umniyyah \\ Jurusan Sastra Indonesia, Fakultas Ilmu Budaya, Universitas Jember \\ zahraniya333@gmail.com
}

Diterima 2 November 2017/Disetujui 2 Januari 2018

\begin{abstract}
This study discusses two short stories part of Akar Pule anthology written by Oka Rusmini. In this study, the writer attempts to reveal, analyze, dan describe physical and psychological oppressions experienced by the female character. In this study the writer uses qualitative method as research method. The author voices her thoughts by presenting the female characters and their problem caused by male characters (men). In these short stories female characters (women) are placed in weaker position than men. The patriarchal system which is deeply rooted in Balinese culture gives more oppression towards women making Balinese women more powerless and forcing them to obey the customs that disadvantage them.
\end{abstract}

Keywords: literary work, radical feminism, patriarchal system

\section{Pendahuluan}

Menurut arti leksikal, feminisme adalah gerakan perempuan yang menuntut persamaan hak sepenuhnya antara kaum laki-laki dan kaum perempuan. Gerakan Feminisme muncul dari gerakan emansipasi perempuan, yaitu proses pelepasan diri dari kedudukan sosial ekonomi yang rendah serta pengekangan hukum yang membatasi kemungkinan-kemungkinan untuk berkembang dan melejitkan diri untuk maju (Moeliono dkk. dalam Sugihastuti dan Suharto, 2005:61-62). Pembagian gender antara laki-laki dan perempuan memberikan dampak yang negatif terhadap perempuan sehingga menimbulkan ketidakadilan gender pada perempuan. Perempuan dianggap sebagai makhluk nomor dua dan dipandang rendah, selalu tertindas oleh kaum laki-laki, sehingga kaum perempuan bergerak untuk mengakhiri ketertindasannya dari kaum laki-laki dan menuntut persamaan hak dengan laki-laki.

Kumpulan cerita pendek Akar Pule karya Oka Rusmini menceritakan tentang perempuan yang hidupnya penuh dengan penderitaan karena penindasan laki-laki. Kumpulan cerita pendek tersebut juga menceritakan mengenai kekuasaan laki-laki atas perempuan yang dapat menimbulkan penderitaan bagi perempuan. Kumpulan cerita pendek Akar Pule merupakan sebuah tulisan yang sarat dengan penindasan perempuan oleh lakilaki yang radikal sehingga memunculkan pemikiran tentang perjuangan kaum perempuan yang membela kaumnya yang tertindas oleh laki-laki. 


\section{Metode}

Tulisan ini bertujuan mengungkap, menganalisis, dan mendeskripsikan penderitaan para tokoh perempuan di dalam kumpulan cerita pendek Akar Pule yang mengisahkan keterkungkungan karena harus tunduk dengan aturan adat yang berlaku. Penelitian ini menggunakan metode penelitian kualitatif deskriptif. Membahas feminisme tidak terlepas dari kritik sastra feminisme, yaitu salah satu disiplin ilmu kritik sastra yang lahir sebagai respon berkembangluasnya feminisme di berbagai penjuru dunia. Moeliono dkk. (dalam Sugihastuti dan Suharto, 2005:61) menyatakan bahwa feminisme adalah gerakan kaum perempuan yang menuntut persamaan hak sepenuhnya antara kaum perempuan dan kaum laki-laki. Persamaan itu meliputi semua aspek kehidupan, baik dalam bidang politik, ekonomi, maupun sosial budaya (Djayanegara dalam Sugihastuti dan Suharto, 2005:61). Pengertian feminisme menurut Geofe (dalam Sugihastuti dan Suharto, 2005:61) merupakan kegiatan terorganisasi yang memperjuangkan hak-hak dan kepentingan perempuan. Jika perempuan memiliki hak yang sederajat dengan laki-laki, berarti perempuan bebas menentukan dirinya sendiri sebagaimana yang dilakukan oleh laki-laki selama ini. Irhomi (dalam Sugihastuti dan Suharto, 2005:61) menyebut hal tersebut sebagai otonomi perempuan. Feminisme merupakan gerakan kaum perempuan untuk memperoleh otonomi atau kebebasan menentukan dirinya sendiri. Kemunculan feminisme diawali dengan gerakan emansipasi perempuan, yaitu proses pelepasan diri kaum perempuan dari kedudukan sosial ekonomi yang rendah, serta pengekangan hukum yang membatasi kemungkinan-kemungkinan untuk berkembang dan maju (Moeliono, dkk. dalam Sugihastuti dan Suharto, 2005:61-62).

Menurut Fakih (2001:84-98), ada empat aliran feminisme yang paling menonjol yaitu feminisme liberal, feminisme radikal, feminisme marxis, dan feminisme sosial. Feminisme liberal menempatkan perempuan memiliki kebebasan secara penuh dan individual, menyatakan bahwa kebebasan dan kesamaan berakar pada rasionalitas dan pemisahan antara dunia privat dan publik, menyadarkan perempuan bahwa mereka adalah golongan yang tertindas. Feminisme marxis memandang bahwa penindasan perempuan adalah bagian dari penindasan kelas dalam hubungan produksi. Persoalan perempuan selalu diletakkan dalam kerangka kritik atas kapitalisme. Menurut Marx (dalam Fakih 2001: 86), hubungan antara suami dan istri serupa dengan hubungan antara proletar dan borjuis, serta tingkat kemajuan masyarakat dapat diukur dari status perempuannya. Sejarah terpuruknya status perempuan bukan disebabkan oleh perubahan teknologi, melainkan karena perubahan dalam organisasi kekayaan (Engels dalam Fakih, 2 001:87). Feminisme sosial melakukan sintesis antara metode historis materialis Marx dan Engels dengan gagasan personal of political dari kaum feminis radikal. Bagi feminisme sosialis, penindasan perempuan terjadi di kelas mana pun, bahkan revolusi sosialis ternyata tidak serta merta menaikkan posisi perempuan. Atas dasar itu mereka menolak visi Marxis klasik yang meletakkan eksploitasi ekonomi sebagai dasar penindasan gender. Kritik terhadap eksploitasi kelas dari sistem kapitalisme harus dilakukan pada saat yang sama dengan disertai kritik ketidakadilan 
gender yang mengakibatkan dominasi, subordinasi, dan marginalisasi atas kaum perempuan (Fakih, 2001: 89-90).

Dalam analisis ini, penulis memfokuskan pada aliran feminisme radikal. Feminisme radikal menganggap bahwa pokok permasalahan perempuan adalah laki-laki sehingga perempuan perlu menghindari atau melawan. Para penganut feminisme radikal tidak melihat adanya perbedaan antara tujuan personal dan politik, unsur-unsur seksual atau biologis sehingga dalam melakukan analisis tentang penyebab penindasan terhadap kaum perempuan oleh laki-laki, mereka menganggapnya berakar pada jenis kelamin laki-laki itu sendiri beserta ideologi patriarkinya. Dengan demikian, kaum laki-laki secara biologis maupun politis adalah bagian dari permasalahan. Bagi kaum perempuan, patriarki adalah ideologi penindasan oleh laki-laki yang memiliki kekuasaan superior dan privilege ekonomi (Eisenstein dalam Fakih, 2001:84-85). Hal tersebut terjadi karena pembagian gender yang melekat pada laki-laki dan perempuan. Gender seringkali menjadikan laki-laki sebagai kaum yang lebih kuat daripada perempuan. Hal tersebut juga didukung oleh melekatnya budaya patriarki dalam masyarakat yang menempatkan laki-laki sebagai makhluk pertama. Fitalaya (dalam Anshori dkk., 1997:26) menjelaskan bahwa kesetaraan gender belum dapat sepenuhnya diwujudkan karena masih banyak praktek diskriminasi terselubung atau ketidaksetaraan tindakan terhadap peran gender, baik di sektor domestik maupun publik yang khusus menimpa perempuan. Akibatnya, penindasan dan kekerasan seringkali diterima oleh perempuan dari laki-laki sebagai bentuk dari penguasaan laki-laki. Situasi tersebut menjadi lebih parah karena: posisi ketidakberdayaan (powerless) kaum perempuan dalam mengakhiri tindakan-tindakan ketidaksetaraan gender dan kurangnya apresiasi terhadap beban kerja kaum perempuan dengan tidak tersedianya ukuran-ukuran dimensi kerja yang dapat merangkum berbagai kegiatan perempuan yang tidak selalu dirupiahkan (Fitalaya dalam Anshori dkk., 1997:27). Perbedaan gender dapat dijelaskan melalui perbedaan biologis atau psikologis antara laki-laki dan perempuan. Menurut aliran radikal, kekuasaan laki-laki atas perempuan, yang didasarkan pada pemilikan dan kontrol kaum laki-laki atas kapasitas reproduktif perempuan telah menyebabkan penindasan pada perempuan. Hal tersebut mengakibatkan ketergantungan perempuan secara fisik dan psikologis kepada laki-laki. Feminisme radikal merupakan aliran yang bertumpu pada pandangan bahwa penindasan terhadap perempuan terjadi akibat sistem patriarki. Sistem itulah yang menyebabkan ketidakadilan dan penindasan terhadap perempuan. Aliran feminisme radikal juga memprotes kekerasan yang dilakukan laki-laki terhadap perempuan, baik dalam keluarga maupun dalam masyarakat pada umumnya. Bentuk-bentuk penindasan yang disebabkan oleh sistem patriarki termanifestasikan dalam tindakan-tindakan yang merendahkan perempuan, seperti kekerasan fisik dan kekerasan psikis, pelecehan seksual serta perdagangan perempuan. Feminisme radikal menyatakan bahwa penindasan terhadap perempuan merupakan sebuah persoalan yang bersifat fundamental (Fitalaya dalam Anshori dkk., 1997:22-23). 


\section{Hasil dan Pembahasan}

Analisis dalam penulisan ini ditekankan pada kritik sastra feminisme radikal yang menyatakan penindasan terhadap perempuan akibat sistem patriarki. Masalah yang akan dibahas dalam kumpulan cerita pendek Akar Pule melalui kritik sastra feminisme radikal adalah kekerasan terhadap perempuan meliputi dominasi laki-laki terhadap perempuan dan kekuatan perempuan. Sebenarnya, kaum perempuan sudah berhasil menyetarakan kedudukan dan derajatnya dengan kaum laki-laki dalam bidang politik, ekonomi, dan pendidikan. Namun, masih banyak terjadi hal-hal buruk yang menimpa perempuan dan belum mendapatkan kesetaraan hak, kedudukan, dan derajat dengan laki-laki dalam masyarakat, masih menjadi kaum tertindas yang sering mengalami kekerasan. Hal tersebut terjadi karena pembagian peran gender yang kerap merugikan perempuan. Konstruksi sosial yang dibangun oleh masyarakat telah menimbulkan ketidakadilan gender pada perempuan. Akibatnya, perempuan sering menjadi korban dominasi laki-laki. Masalah ketidakadilan gender yang menimpa perempuan sama dengan permasalahan feminisme radikal yang menyatakan bahwa dominasi laki-laki merupakan akar semua permasalahan perempuan. Feminisme radikal merupakan aliran feminisme yang menyatakan bahwa penguasaan fisik perempuan oleh laki-laki, seperti hubungan seksual adalah bentuk penindasan terhadap kaum perempuan (Sofia, 2003:13). Analisis feminisme radikal yang akan dibahas dalam kumpulan cerita pendek Akar Pule karya Oka Rusmini yaitu dominasi laki-laki terhadap perempuan (kekerasan pada perempuan, perempuan sebagai objek seksual, dan perdagangan perempuan) dan kekuatan wanita (penolakan dan prinsip perempuan dan mengakhiri penindasan laki-laki).

\subsection{Cerita Pendek Tiga Perempuan}

Cerita pendek yang berjudul Tiga Perempuan mengisahkan penderitaan tiga perempuan sedarah yang dikhianati suaminya. Pengkhianatan laki-laki menimbulkan dampak yang sangat merugikan perempuan. Tokoh Aku tergolong sebagai perempuan yang tidak pernah mendapatkan kasih sayang dari orang tuanya. Masa lalunya sangat kelam. Ajinya meninggalkan tokoh Aku, adik, dan ibunya demi menikahi seorang janda. Ibu tokoh Aku pun meninggalkan tokoh Aku dan adiknya demi menikah dengan laki-laki lain. Masa lalu tanpa kasih sayang orang tua adalah perjalanan yang berat bagi tokoh Aku dan adiknya. Tokoh Aku melakukan resistensi terhadap sistem kasta dengan cara menikahi lakilaki di luar agamanya. Pernikahan selama 15 tahun yang dipertahankan oleh Tokoh Aku dibalas dengan pengkhianatan oleh suaminya. Kehadiran sosok perempuan lain membuat banyak perubahan dalam diri suami tokoh $\mathrm{Aku}$, sering berlaku kasar $(A P: 8)$ dan mengeluarkan kata-kata kasar (AP: 11).

"Dia itu istri orang? Aku tidak mungkin sehina itu! Aku bekerja! Ada hubungan kerja! Hubunganku dengan dia tidak seperti yang kamu bayangkan!” kata lelakiku sambil marah-marah. Dia juga sering mengamuk. Bahkan sebuah guci keramik dari Cina hadiah dari sahabatku dihancurkannya. (AP:8) 
Lelakiku pun menjadi sangat kasar. Kata-kata kotor, fuck you, bangsat, dan berbagai makian lain berhamburan dari bibirnya. (AP: 11)

Tokoh Aku mendapatkan perlakuan tidak menyenangkan dari suaminya. Ketika tokoh Aku mengungkapkan kecurigaan atas perselingkuhan suaminya, suami tokoh Aku justru marah dan berbuat kasar. Hal tersebut dapat digolongkan sebagai kekerasan fisik. Kekerasan fisik dan psikis yang dialami oleh tokoh Aku membuatnya trauma, tetapi tokoh Aku tetap berusaha menjalankan perannya sebagai seorang ibu yang baik untuk anak-anaknya.

Cara pengarang mendeskripsikan pemikirannya mengenai perjuangan tokoh perempuan yang berbeda karakter dalam menghadapi persoalan hidupnya. Cerita pendek Tiga Perempuan menantang pembaca untuk memandang suatu fenomena dengan cara baru, misalnya pandangan Tokoh Aku yang tidak menganggap penting latar belakang kasta sejak awal kemunculannya. Tokoh Aku adalah seorang perempuan berkasta Brahmana yang berani dengan tegas menunjukkan penolakannya terhadap sistem adat-istiadat yang mengikat. Ia melakukan pemberontakan untuk mewujudkan impiannya agar menjadi perempuan yang merdeka dan tidak lagi terikat oleh sistem itu. Pencerita Aku primer berbeda perempuan Brahmana lainnya yang bangga dengan darah berkasta Brahmana yang mengalir dalam tubuhnya. Baginya, menjadi perempuan Brahmana tidak dapat memberikan ketenangan dalam hidupnya karena harus mematuhi semua peraturan yang membuatnya merasa tidak nyaman. Dalam hal ini terjadi suatu proses dekonstruksi yaitu hilangnya rasa bangga memiliki kasta tinggi dan berusaha membebaskan diri dari rasa terkungkung sebagai perempuan Brahmana dengan cara menikah dengan laki-laki di luar kasta Brahmana. Tokoh Aku berperan sebagai pahlawan perempuan yang melawan dominasi maskulin yang telah melekat pada sistem patriarki dan bertindak sebagai perempuan yang berusaha memprotes sistem patriarki yang dianut keluarganya dan menginginkan keluar dari sistem tersebut.

Pembahasan mengenai perempuan dalam Tiga Perempuan yang mengalami permasalahan dengan pernikahannya, hampir setiap perempuan dalam Tiga Perempuan mengalami peristiwa buruk dalam pernikahannya. Tiga Perempuan mengungkap sebuah perbedaan pemikiran, para perempuan merasa tidak bahagia dengan adanya pernikahan dan menganggap perempuan adalah makhluk yang menderita karena adanya pernikahan. Penderitaan tokoh Aku bukan hanya karena perlakuan laki-laki yang telah menikahinya, mereka menderita karena perlakuan keluarga besar yang mengucilkan dan membuangnya. Pernikahan tokoh Aku dengan lelaki yang berasal dari luar Brahmana membuatnya dibuang oleh keluarga besar. Penceritaan terus mengalir ketika tokoh Aku mengisahkan perkenalannya dengan seorang lelaki yang selanjutnya menjadi suaminya. Setelah mengetahui bahwa tokoh Aku telah menikah, pihak keluarga besar membuangnya dan menganggapnya tidak pernah ada. Tokoh Aku telah terbiasa hidup mandiri dan tidak bergantung kepada orang lain sehingga tokoh Aku tidak gelisah ketika dibuang oleh keluarganya. Permasalahan pernikahan yang dialami menyebabkan tokoh Aku berpikir bahwa derajat manusia tidak dapat dinilai dari kasta yang melatarbelakanginya. Sebagai 
perempuan berlatar belakang Ida Ayu, tokoh Aku tetap menganggap bahwa derajat manusia sama dan tidak bergantung dari ikatan kasta. Tokoh Aku pun merasa pengeluaran dirinya dari keluarga besar semakin memberikan kebebasan terhadap dirinya.Tokoh Aku justru merasa semakin leluasa untuk berpikir dan bertindak karena tidak ada aturan adat yang mengikatnya. Sebagai perempuan Brahmana, tokoh Aku banyak mendapatkan peraturan mengenai cara bergaul, tokoh Aku diharuskan bergaul dengan orang-orang yang berkasta sama sehingga tokoh Aku harus membatasi pergaulannya dengan orang di luar Brahmana. Sejak awal, tokoh Aku tidak menyetujui aturan-aturan yang dianggap mengikat perempuan sehingga pengeluaran dirinya dari kasta Brahmana justru memberikan kebahagiaan tersendiri karena tidak ada lagi aturan yang mengikatnya.

Bagi Tokoh Aku penghormatan terhadap seseorang tidak dilakukan berdasar kastanya karena kasta tidak mencerminkan tingginya pernghormatan terhadap seseorang. Tokoh Aku mempunyai pemikiran yang berbeda mengenai kasta dibandingkan pemikiran keluarga besarnya karena sejak kecil kehidupannya kurang menyenangkan. Perceraian orang tua membuat masa kecilnya terombang-ambing dan hidup di luar Griya (AP: 21). Sebagai keturunan Brahmana yang hidup di luar lingkungan griya, Tokoh Aku mempunyai anggapan yang berbeda mengenai derajat seseorang. Menurutnya, derajat seseorang tidak dapat ditentukan melalui kastanya, sedangkan menurut keluarga besarnya yang tinggal di dalam lingkungan griya, kasta sangat mempengaruhi tinggi rendahnya derajat seseorang. Hidup di lingkungan luar griya membuat Tokoh Aku mempunyai pemikiran yang lebih luas dan bebas sehingga Tokoh Aku memiliki cara pandang yang berbeda dengan keluarga besarnya.

Sistem patriarki adalah suatu kekuasaan laki-laki, hubungan kuasa dengan laki-laki menguasai perempuan, atau sistem yang membuat perempuan dapat dikuasai dengan berbagai cara (Bhasin, 1996: 1). Tiga Perempuan memaparkan suburnya sistem patriarki di Bali. Sistem kekerabatan patrilineal yang dianut oleh masyarakat Bali menempatkan kaum laki-laki pada kedudukan yang lebih tinggi. Laki-laki berkedudukan sebagai penerus nama besar keluarga, penerus keturunan, dan berperan penting dalam pengambilan keputusan keluarga maupun masyarakat luas. Dalam masyarakat yang menganut sistem kekerabatan partilineal, perempuan mempunyai kedudukan yang sangat rendah, tidak dapat melanjutkan keturunan, tidak dapat menjadi penerus nama besar keluarga karena dalam ikatan perkawinan perempuan mengikuti suami. Laki-laki pun dapat dengan bebas menentukan sendiri perempuan yang akan menjadi istrinya karena perempuan akan mengikuti kasta laki-laki tersebut. Hal tersebut memudahkan kaum laki-laki untuk memilih istri karena lakilaki tidak akan dikeluarkan dari kastanya jika menikah dengan perempuan di luar kastanya. Misalnya laki-laki dari kasta Brahmana menikah dengan perempuan dari kasta di bawah Brahmana, maka perempuan tersebut akan mengikuti kasta suaminya dan bergelar Ni Jero setelah mengikuti serangkaian upacara. Hal lain terjadi terhadap perempuan Brahmana yang harus memilih laki-laki sekasta agar tidak mengalami penurunan kasta dan dikeluarkan dari kasta Brahmana. Setelah dikeluarkan dari kastanya, perempuan tersebut 
benar-benar dianggap tidak pernah ada dan tidak pernah mempunyai hubungan dengan keluarga besarnya.

Hal tersebut dialami oleh tokoh Aku yang dibuang oleh keluarganya karena menikah dengan laki-laki di luar kasta dan agamanya. Perjuangan keras dilakukan oleh tokoh Aku dalam menghadapi diskriminasi adat yang menimpa kehidupannya. Tokoh Aku, harus berjuang dari titik terendah bersama suaminya karena lebih memilih cinta dibandingkan derajat. Baginya, cinta memiliki kedudukan yang lebih tinggi daripada derajat. Masa lalu yang mandiri sejak kecil membuatnya harus berani mengambil keputusan sendiri, termasuk ketika mengambil keputusan untuk menikah dengan laki-laki di luar kastanya.

Pernikahan perempuan Brahmana dengan laki-laki di luar kastanya dianggap sebagai aib bagi keluarga pihak perempuan karena perempuan tersebut akan dikeluarkan dari kastanya. Dalam urusan pernikahan, kasta sering menimbulkan masalah dan menjadi penghalang bagi pasangan yang berbeda kasta. Sama seperti pernikahan beda agama, pernikahan beda kasta di Bali pun harus dihindari. Kemajuan zaman tidak dapat mengubah hukum adat yang tetap berlaku di dalam masyarakat Bali. Pernikahan di Bali bersifat patrilineal, seorang perempuan setelah menikah dan menjadi istri akan bergabung dengan keluarga suaminya sehingga seorang perempuan dari kasta yang lebih rendah akan merasa sangat terhormat jika dijadikan istri oleh lelaki dari kasta yang lebih tinggi akan ikut kasta suaminya, bahkan pihak keluarga perempuan merasa bangga jika salah seorang anggota keluarganya menikah dengan keturunan Brahmana. Jika seorang perempuan berkasta tinggi menikah dengan lelaki tidak berkasta atau dengan lelaki yang kastanya lebih rendah, perempuan tersebut akan mengalami turun kasta. Pernikahan seperti itu sangat dihindari dan tidak akan mendapatkan restu dari keluarga besar pihak perempuan karena dianggap sebagai aib.

\subsection{Cerita Pendek Sipleg}

Perempuan yang terkungkung menyuarakan kisahnya dan kisah ibunya yang menjadi korban dari sistem patriarki, perempuan tersebut adalah Luh Sipleg. Luh Sipleg terkungkung karena posisinya sebagai anak perempuan dianggap tidak penting sehingga dijual, sedangkan Ni Luh Songi terkungkung karena ambisi suaminya untuk mendapatkan bayi laki-laki. Luh Sipleg pun menceritakan masa lalu Ni Luh Songi (ibunya). Songi tidak dapat melahirkan anak lelaki, semua anak yang dilahirkannya adalah perempuan. I Wayan Sager, suaminya, menganggap semua kesialan yang terjadi kepadanya disebabkan Songi tidak dapat melahirkan anak laki-laki. Kehadiran anak laki-laki dianggap sangat penting karena hanya anak laki-laki yang dapat melanjutkan keturunan. Hal tersebut membuat Songi mengalami penderitaan. Demi mengikuti ambisi suaminya, Songi terus-menerus hamil sampai rahimnya mengalami kerusakan dan dinyatakan tidak dapat hamil lagi. Dalam hal ini perempuan sangat dirugikan. Perempuan yang seharusnya merasakan kebahagiaan dalam pernikahan harus merelakan kehilangan rahimnya karena terlalu patuh kepada suaminya. Sebagai suami yang penuntut dan tidak pernah menafkahi istri, Sager dianggap 
sebagai laki-laki yang tidak bertanggung jawab, sedangkan kepatuhan Songi kepada suaminya justru harus dibayar mahal dengan kerusakan rahimnya.

Seorang ibu rumah tangga mempunyai peran yang paling penting untuk menciptakan pola hidup sehat yang bisa menghindarkan semua penghuni rumah dari berbagai jenis ancaman penyakit. Salah satu bentuk tanggung jawab yang harus dipikul oleh ibu rumah tangga untuk menjaga kesehatan keluarga adalah setiap hari harus selalu membuat dan menyediakan makanan yang sehat, bergizi dan tetap enak untuk dinikmati serta sesuai dengan standar dari pola hidup sehat. Karena lebih sering tinggal di rumah, ibu rumah tangga juga berkewajiban untuk menjaga kebersihan lingkungan tempat tinggal demi kesehatan keluarganya. Selain membuat makanan, tugas lain ibu rumah tangga untuk menjaga kesehatan keluarga adalah memberi pendidikan untuk anak sejak usia belia agar dapat mengatur pola hidup sehat dalam menjalani kegiatan mereka setiap hari. Peran seperti itu tidak dijalankan oleh Ni Luh Songi. Ni Luh Songi tidak pernah memperhatikan kesehatan anak-anak perempuannya karena sibuk mewujudkan ambisi suaminya untuk mendapatkan anak laki-laki.

Kehadiran anak laki-laki membuat kehidupan Ni Luh Songi menjadi terkungkung. Songi dihadapkan dengan pernyataan suaminya bahwa hanyalah anak laki-laki yang dapat meneruskan keturunan. Hal tersebut membuktikan bahwa sistem patrilineal masih tumbuh subur di Bali. Garis keturunan laki-laki masih dianggap penting sehingga anak perempuan dikesampingkan. Ambisi memiliki anak laki-laki menyebabkan Songi harus tunduk dengan aturan adat yang menganggap anak lelaki memiliki peran penting dibandingkan anak perempuan. Songi terus-menerus hamil tanpa memperhatikan kondisi kesehatannya sehingga rahimnya menjadi rusak. Hal tersebut membuktikan bahwa sistem patriarki dapat membelenggu posisi perempuan sehingga perempuan tetap menjadi pihak yang dirugikan, dalam hal ini Songi menjadi sangat rugi karena harus kehilangan rahimnya. Selain Songi, anak-anak perempuan Songi (salah satunya adalah Luh Sipleg) mengalami kerugian karena tidak mendapatkan kasih sayang dari seorang ibu yang selalu sibuk dengan kehamilannya. Anak-anak perempuan Songi menjadi pihak yang terkungkung karena tidak pernah mendapatkan haknya sebagai anak perempuan.

Ketika perempuan mengalami kehamilan dan melahirkan, rahim akan mengalami perubahan. Rahim mengalami luka karena perubahan tersebut sehingga rahim membutuhkan waktu untuk proses penyembuhan dan pengembalian seperti kondisi semula. Kehamilan yang ideal berjarak dua tahun karena dua tahun dapat memberikan waktu untuk kesembuhan rahim. Kehamilan dengan jarak yang dekat yang terjadi berulang-ulang seperti yang dialami Songi memberikan dampak buruk pada rahimnya. Kerusakan yang dialami rahim Songi memberikan dampak buruk yaitu Songi tidak dapat hamil lagi. Kesuburan yang dulu digunakan Songi untuk memenuhi keinginan suaminya dalam mengikuti tradisi patriarki, kini harus hilang karena ambisi tersebut. Bidang-bidang kehidupan perempuan yang normalnya berada di bawah kontrol patriarki. Pertama, daya produktif atau tenaga kerja perempuan. Laki-laki mengontrol produktivitas perempuan di dalam maupun di luar urusan rumah tangga. Kedua, laki-laki juga mengontrol daya reproduktif perempuan. 
Banyak kasus dalam masyarakat, perempuan tidak memiliki kebebasan dalam menentukan jumlah anak yang diinginkan, dan waktu untuk melahirkan anak. Ketiga, kontrol laki-laki juga berlaku atas seksualitas perempuan. Perempuan diharuskan memberikan pelayanan seksual kepada laki-laki sesuai dengan keinginan dan kebutuhan pihak laki-laki. Keempat, gerak perempuan dikontrol untuk mengendalikan seksualitas, produksi, dan reproduksi mereka. Kelima, laki-laki juga mengontrol harta milik dan sumber daya ekonomi lain dengan jalan sistem pewarisan dari laki-laki ke laki-laki (Bahsin dalam Sugihastuti dan Saptiawan, 2007:94). Ni Luh Songi dianggap sebagai perempuan yang terkungkung karena sistem patrairki karena tidak memiliki hak untuk mengontrol daya reproduktifnya.

Ketika berusia 16 tahun Luh Sipleg dijual oleh orang tuanya demi membayar hutang orang tuanya. Hal tersebut disebabkan karena orang tua Luh Sipleg menganggap anak perempuan tidak penting dan tidak perlu dipertahankan. Kemiskinan telah membuat Luh Sipleg tidak mempunyai pilihan dalam kehidupannya. Penjualan Luh Sipleg kepada Ni Ketut Jinah mengharuskan Luh Sipleg menikah dengan I Wayan Payuk dan tidak pernah merasakan bahagia karena kehilangan haknya sebagai perempuan. Walaupun I Wayan Payuk adalah lelaki yang baik, Luh Sipleg tetap merasa tidak bahagia karena Luh Sipleg merasa terikat dengan hutang orang tuanya dan Luh Sipleg berperan sebagai alat pembayaran hutang. Luh Sipleg menjelma menjadi perempuan pendiam, bahkan mertuanya menganggapnya perempuan tuna wicara. Luh Sipleg tidak pernah berbicara dengan mertuanya, tidak pernah menjawab semua pertanyaan dari mertuanya, selalu diam dan tidak pernah mempedulikan mertuanya. Luh Sipleg menyimpan dendam untuk orang-orang yang berkaitan dengan penjualan dirinya, yaitu orang tuanya sebagai penjual dan mertuanya sebagai pembeli. Peristiwa penjualan Luh Sipleg menempatkannya di wilayah yang sangat tidak nyaman dan tidak kondusif bagi kehidupannya. Luh Sipleg berada di dalam kondisi terkungkung akibat perbuatan orang tuanya sehingga pencerita Aku Luh Sipleg merasa tidak pernah mendapatkan kebahagiaan sepanjang berada di dalam kondisi tersebut. Luh Sipleg tidak mendapatkan haknya sebagai perempuan yang bebas sejak sebelum menikah dan setelah menikah sehingga Luh Sipleg berada di dalam kondisi yang tidak memberikan kenyamanan bagi hidupnya.

\section{Kesimpulan}

Akar Pule berusaha mengungkapkan ketidakadilan akibat sistem yang telah mengakar kuat di dalam masyarakat. Akar Pule pun secara dominan membahas masalah budaya Bali yang sangat kental dengan pembagian kasta. Adanya pembedaan antarmanusia dapat menimbulkan berbagai ketidakadilan dalam masyarakat. Hal tersebut membuat beberapa tokohnya berusaha menentukan sikap untuk menunjukkan suatu perlawanan dan berusaha mewujudkan impian untuk mendapatkan kebebasan yang diinginkan. Seluruh perempuan di Indonesia, bahkan di dunia, pada dasarnya memiliki kesamaan dalam hal gender, tetapi latar belakang budaya dan adat membuat setiap perempuan di berbagai daerah mempunyai persoalan dan cara sendiri dalam menentukan pilihan untuk menjalani kehidupannya. Budaya dan adat pun dapat menjadi salah satu faktor yang dapat 
mempengaruhi cara pandang dan cara berpikir seseorang. Oka Rusmini sebagai perempuan pengarang telah beberapa kali mengangkat permasalahan pernikahan berbeda kasta dalam karya sebelumnya, misalnya dalam novel Tarian Bumi, novel Kenanga, dan novel Tempurung. Pernikahan sesama kasta maupun berbeda kasta masih sering terjadi di Bali. Peraturan adat dalam hal pernikahan tergolong masih merugikan pihak perempuan dan menimbulkan adanya suatu diskriminasi bagi perempuan. Bagi perempuan Brahmana yang menikah dengan laki-laki berkasta di luar Brahmana akan mengalami penurunan kasta mengikuti kasta suaminya dan dikeluarkan dari keluarga besar Brahmana, perempuan itu pun harus meninggalkan rumah dan keluarganya.

Kesimpulan dalam analisis feminisme radikal terhadap kumpulan cerita pendek Akar Pule adalah bahwa kekerasan yang dilakukan laki-laki terhadap perempuan akan berdampak buruk bagi perkembangan jiwa dan raga perempuan. Selain mengalami penderitaan fisik, perempuan juga dapat mengalami penderitaan psikis yang dapat membuat perempuan trauma dan takut menghadapi suatu hal. Walaupun saat ini perempuan telah mengalami kemajuan dalam semua bidang, tetapi tidak dapat dipungkiri bahwa keotoriteran laki-laki masih membelenggu mereka. Dalam hal ini, perempuan harus sadar bahwa mereka masih berada dalam lingkaran sistem patriarki yang mengekang perempuan. salah satu cara untuk memberikan penyadaran dan respon terhadap keadaaan tersebut adalah pendidikan.

\section{Daftar Pustaka}

Anshori, D. S. 1997. Membincangkan Feminisme: Refleksi Muslimah atas Peran Sosial Kaum Wanita. Bandung: Pustaka Hidayah.

Bhasin, Kamla. 1996. Menggugat Patriarki, Pengantar Tentang Persoalan Dominasi Terhadap Kaum Perempuan. Yogyakarta: Bentang.

Fakih, M. 2001. Analisis Gender dan Transformasi Sosial. Yogyakarta: Pustaka Pelajar.

Sofia, A. 2009. Aplikasi Kritik Sastra Feminisme: Perempuan dalam Karya-karya Kuntowijoyo. Yogyakarta: Pustaka Pelajar.

Sugihastuti \& Suharto. 2005. Kritik Sastra Feminis: Teori dan Aplikasinya.Yogyakarta: Pustaka Pelajar. 